\title{
The Problem of Political Science and Practical Politics
}

\author{
Claire Donovan and Phil Larkin
}

The Australian National University

We reflect on the reasons why there is not a greater and more fruitful relationship between those who seek to understand policy and the political process from academia and those with a similar task in 'practical politics'. We attribute this lack of engagement to three core factors: (1) from without, instrumental government visions of political science perpetuate the view that the discipline exists to serve those with power; (2) from within, scientism and abstraction diminish the discipline's stock of 'usable' product for 'practical politics'; and (3) where relevant research exists, its uptake is hampered by limited communication between these spheres.

In the first issue of Politics under their management, the Sussex Editorial Team chose to highlight two perennial problems in the study of British Politics: (1) 'what do we understand by the discipline of political science?' and (2) 'what is the place of the discipline in the wider world?' (The Sussex Editorial Team, 2000, pp. 51-52). Six years later these questions still hang awkwardly in the air, and are central to the concerns of this article. To take these points in reverse order, the team qualified what they perceived to be the lack of impact of political science beyond academia:

'What is and what should be the contribution of the discipline to the things that it studies? It is ironic that the raw material of politics is popularly accessible and understood, yet our discipline has not taken advantage of this. It has achieved neither the status nor purchase upon the popular and political that one might have expected of it. Other social sciences have been more successful in this respect and we might want to consider why this is the case.' (The Sussex Editorial Team, 2000, p. 51)

They pressed this issue further by asking, 'How can we make [political science] more relevant to government, NGOs, practitioners and ordinary citizens?' (ibid., p. 52). The main task of our article is to consider the relationship between political science and 'practical politics' in Britain, and specifically the performance of academic political science in informing public policy and providing a product that is readily usable by practitioners, be they policymakers from government or the civil service, or those seeking to influence, challenge or simply understand policy from the backbenches, NGOs, unions, trade associations, business or the media. We are led similarly to ask what the contribution of political science should be to the object of its study, and what and whom political science should be for. This allows us to reflect more deeply on why political science's often problematic relationship with 'practical politics' is failing and engenders a level of engagement that continually falls below expectations. 
The Sussex Team also ruminated on the scientific status of political science, an issue which we take to be closely bound to understanding the place of the discipline in the wider world, and with a twist, to answering the question of how we can make political science more relevant to practical politics. They asked:

'Do we accept the basic premise that the study of politics in all its varied aspects can actually be regarded as a coherent discipline, with what amounts to a canon of work, informed by cumulative knowledge and a broad agreement regarding scope and methods? Moreover, do we accept the idea of a 'science' of politics?'

(The Sussex Editorial Team, 2000, p. 51)

In the British context we have chosen quite deliberately to discuss 'political science' rather than 'political studies', but rather than debating the virtues of 'positivist', interpretative or pluralist approaches (as we have done elsewhere: see Donovan, 2005), we maintain that the profession's turn towards scientism and theoretical abstraction, rather than the dominance of particular methods or modes of analysis, limits the stock of 'usable' political science which can inform those engaged in practical politics.

The aim of this article is not to chastise political science for a supposed lack of relevance, nor say that genuinely policy-relevant political science does not exist, nor suggest that the role of political science should be primarily to solve the problems of practitioners or 'end-users'. Rather, the point is to reflect on the reasons why there is not a greater and more fruitful relationship between those who seek to understand policy and the political process from academia and those in a similar task engaged in 'practical politics'.

\section{The challenge from without: instrumentalism}

Government desire for publicly-funded social science research to produce and promote outcomes of direct policy relevance is a long-standing one, an aspiration coupled with the instrumentalist view that state-sponsored political science research should be of service to the state. To present a potted history, the Social Science Research Council (SSRC) was, for example, founded on technocratic, Fabian high hopes of social science as a driver of government planning (Heyworth, 1965). Two decades later the promise of social science had plummeted to its nadir. Largely driven by the personal demons of Education Secretary Keith Joseph, the SSRC narrowly avoided being disbanded by the Thatcher administration (Rothschild, 1982). This episode signalled the final demise of consensus politics and was part of a broader backlash fuelled by disillusionment with what social science had delivered for its political paymasters: Fabianism (an anathema to the Tories) was steeped in naïve positivism and had oversold the potential of social science, which inevitably led to disappointment; and social scientists were seen to be remote from government and openly critical of its policies, so their research was branded as ideologically motivated and hence 'unscientific'. ${ }^{1}$ The current vogue for 'evidencebased policy', seen as a cornerstone of Blairite thinking, is the latest incarnation of the urge towards research relevance and has exposed a continuing uneasy relationship between political practitioners and academe. For example, in a speech to 
the ESRC David Blunkett, as Secretary of State for Education and Employment, infamously bemoaned the lack of a readily usable end product (Blunkett, 2000), and he was in turn accused of promulgating an illiberal and anti-intellectual government vision of uncritical social science devoted to providing 'evidence' to justify government policy initiatives (Hammersley, 2001).

However, academic hostility towards work of a more applied nature is not solely a reaction to government instrumentalism and goes beyond legitimate hostility to the model of social science set out by Blunkett. Academic antagonism towards 'relevance' thus conceived is a sentiment often accompanied by the tendency to devalue the scholarly merit of practitioner-oriented or practitioner-led contributions, or the belief that the genesis of influential research which has practical impact is serendipitous and cannot be prescribed (Hardin, 2002, p. 183). As a corollary to this there are, of course, political scientists who conduct a large amount of applied research under contract from various parts of government or through the dual funding system. Yet these remain the exception, and as their contracted work is unlikely to have an impact on the mainstream of the discipline, academic advancement is largely dependent on their ability to turn this applied work into 'unapplied' political science publications.

This brings us to consider further contrary values about the purpose of political science research held by government and by the profession, and the conflicting incentives government provides to academia compared with the product it desires. In order for political science's potential practical contribution to be better realised there need to be the appropriate incentives in place. At the moment, academic prestige is a reflection of academic publication - both individually and departmentally - and there is little return in engaging in the political process beyond, at best, a certain residual kudos. The Research Assessment Exercise (RAE) clearly reinforces this tendency, dependent as it is on peer review of academic publications. There is no credit under the RAE for, for instance, giving evidence before a parliamentary Select Committee or for participating in a government policy consultation process. Neither is a young political scientist likely to receive much direct career benefit from a government secondment, no matter the greater understanding of government and the policymaking process that might be gained; it is more likely to be seen as a worrying gap in publication output. Also, while competitive research council funding is to some extent indirectly steered towards supporting government priorities, the success of an award is again measured by the number and citation level of research publications, and not its impact upon practical politics.

To conclude, heavy-handed government instrumentalism, and hostility towards this, goes some way to accounting for disappointing levels of academic engagement with practical politics - a tendency that is, perversely, encouraged by the incentives provided by current policy. But this outcome is reinforced by professional values that are dismissive of applied work and that, implicitly or explicitly, perceive the purpose of political science as distinct from the matters of practical policymaking. To date we find that dewy-eyed government visions of a worthwhile political science are directive yet impracticable, particularly when financial incentives 
mingled with core professional values have led political scientists effectively to shun research which seriously engages with practitioners, preferring to stand outside and gaze inwards at the objects of their study or, as we now discuss, to deal with abstractions so that they need not look at all.

\section{The challenge from within: scientism and abstraction}

The United States has been taken as the paradigm case of political science's turn away from practical political engagement. This has been extensively debated, notably during the 'Perestroika' debate within the American Political Science Association, and responsibility laid firmly at the feet of 'scientism' and the profession's 'technicist' tendency embedded in rational choice theory and the associated pursuit of quantification, which has created a science of politics that has privileged the 'science' at the expense of the 'political' (see Cohn, 1999). For Giovanni Sartori (2004, p. 786), that 'American-type' political science has 'missed, or even dismissed, its applied branch entails that political science is a theory without practice, a knowledge crippled by a know-how void'. The discipline's privileging of the behavioural at the expense of the institutional, the quantitative and the statistical, and the 'theory-research path of inquiry at the expense of the theory-practice nexus' means that it is 'going nowhere' and 'is an ever growing giant with feet of clay'. These sentiments are echoed by Rogers M. Smith (2002, p. 199), who implied there is a sense in which the pursuit of methodological sophistication has diminished the capacity of political science to contribute to the political process, or at least to contribute in a way and in a language in which its relevance can be readily ascertained (see also Almond, 1990). The Perestroikans argued instead for greater methodological pluralism as a means by which political science might be reoriented away from its increasing 'monasticism' and isolation from political and public life, which they claimed was the result of the over-dominance of rational choice approaches.

However, the dominance of 'American-style' political science in the US, or its influence upon UK political science, cannot be the only explanation for a lack of interaction with practical politics. While the Perestroikans believed that the dominant public choice perspective was method driven rather than problem driven, rational choice theory, at least its Virginian variant, was highly politically engaged and used its method to derive clear public policy goals, many of which have been absorbed into the mainstream policymaking discourse in the UK, US and beyond. The recommendations may not have been to everyone's taste, but political irrelevance is hardly a fair accusation, nor is the vigorous pursuit of a particular method a convincing explanation, in itself, for the failure of political science to play a greater practical role. Regardless of the merits of a more methodologically pluralist discipline for the development of political science, there is no inherent reason why such pluralism should prove more successful at producing a political science that can more usefully contribute to public policy and political life (Dryzek, 2003). The experience of political science in the UK highlights this point clearly: British political science has not fallen under the sway of quantitative method and public choice analysis to the extent that the US has and is fairly pluralistic. However, it would be difficult to claim that British political science has been more successfully utilised by policymakers than its American counterpart. 
It is for this reason that we choose not to focus on the virtues of 'positivist', interpretative or pluralist approaches, but pursue the line that the discipline's inclination towards refined abstraction - be it mathematical reasoning or high theory acts also to limit the stock of 'usable' political science which can in fact aid those engaged in practical politics. This is because the raison d'être of modern political science, in whatever form it takes, does not lend itself to practical impact simply because its shared focus is on understanding, explanation, conceptualisation and classification (no matter how elegant or sophisticated that classification is). While conceptualisation, classification and the pursuit of greater theoretical sophistication are, in a sense, what political science is about, as Jane Lewis observes, 'the effort to develop and refine theory ... can become so internally focussed that it becomes hopelessly remote from common sense and real experience' (2003, p. 197). There is a sense in which the development and progress of political science is measured by its increasing abstractness, a pattern seemingly replicated in other social sciences. Policymakers' and practitioners' primary concerns are generally rather different and focus on problem solving, making something work or devising a means by which the ends they desire can be realised.

\section{The need for, and limits of, engagement}

We do not suggest that political science should merely fall into line with the government instrumentalism that we have identified, becoming a 'slave social science' (see Donovan, 2005). But, we maintain that political scientists should be able to engage with practical politics on their own terms and should be able to provide research output that is of value to practitioners. It is because of its focus on understanding, explanation, conceptualisation and classification that political science has the potential to contribute more to practical politics, and more successfully. As Brian Barry notes,

'Granting (for the sake of argument) that [students of politics] have some methods that enable us to improve on the deliverances of untutored common sense or political journalism, what good do they do? The answer to that question is: not much. But if we change the question and ask what good they could do, I believe that it is possible to justify a more positive answer' (Barry, 2004, p. 22).

A clear understanding of how institutions and individuals interact or how different institutions interact with each other can provide clear and useful insights that practitioners can successfully use, making - or perhaps remaking - a political science that 'directs research efforts to good questions and enables incremental improvements to be made' (ibid., 19). In this sense, political science already has the raw material to make this contribution, but it chooses not to utilise it in this way: no doubt, in part, because academics are motivated to present their findings to other academics and not the practitioners within the institutions they study.

It is, however, important to keep expectations realistic, and even were it not for the differences and difficulties discussed above, there are a number of obvious practical obstacles that will hinder the take-up of political science by practitioners: a lack of awareness of that research by policymakers, a need for effective commu- 
nication of relevant research findings by the political scientists, and ignorance of the ways in which these findings might be fed into the policy process (see Edwards, 2004). Proposed solutions directed at the sorts of hindrances stemming from this mutual ignorance have been numerous, and have revolved around greater public relations efforts by, and on behalf of, researchers. For example, an Academy of Learned Societies for the Social Sciences (ALSiSS) review recommends that social scientists should use their websites to advertise better themselves and their work and to make more strenuous efforts to get media coverage (Commission on the Social Sciences, 2003, p. 15). Taking a different tack, an ESRC publication, Influencing the Policymaking Process, outlines the various routes through which an academic might bring their work to the attention of those involved in practical politics: individual MPs, select committees, the civil service or think-tanks for instance (McGrath, 2001). There are also an increasing number of forums established which aim to bring academics and policymakers together: several government departments, notably the Cabinet Office, run regular seminars, and the ESRC has attempted to promote this relationship, notably with its annual Social Science Week. But, despite such initiatives there still remains a distance between social scientists and practitioners. The assumption underpinning these initiatives is evidently that the only thing preventing greater use of social science by practitioners is ignorance: the product is fine and only practitioner awareness needs addressing. Yet, we have argued that this is not the case at all: the orientation and priorities of the discipline work against the production of usable knowledge and more fruitful engagement with practitioners. The type of 'product' that political scientists are generally encouraged to produce is not one that is readily usable by those involved in practical politics, and there are few incentives from within academia or under the RAE to change this.

It would be naïve to assume that a political science which uses the knowledge and insights derived from the systematic and detailed study of political institutions and phenomena, or even concepts, will be simply picked up by those involved in the political process. Policymakers, politicians, unions, NGOs and the rest of the actors involved in practical politics have objectives to pursue, and political science is useful to them only where it helps them to clarify those objectives or to realise them. In many instances, 'politicians would not be helped by advice from political scientists any more than fish would be able to swim better if they got advice from ichthyologists' (Barry, 2004, p. 24); clearly, even at best, only a proportion of 'useful' political science will be taken up and there are numerous 'filters' that might see potentially workable ideas ignored (see Stone, Maxwell and Keating, 2001). And practical matters such as the differences in the time frames to which academics and those involved in practical politics work will clearly persist. But, the concern of the discipline must be less with ensuring the impact of individual pieces of work, or the work of particular individuals, and more with ensuring that there is a 'critical mass' of 'usable' political science to which practitioners can turn. This is still not a guarantee that it will be picked up by political practitioners, but producing research without this aim in mind is a guarantee that this will not happen.

\section{Notes}

We would like to thank Charlie Lees, Rod Rhodes and Paul Taggart for their advice, and the participants of the 'State of the Art' workshop for their valuable comments on an earlier version of this article. 
1 By way of punishment the SSRC was stripped of the title 'Science' and renamed the Economic and Social Research Council (ESRC) in 1984.

\section{References}

Almond, G. (1990), A Discipline Divided: Schools and Sects in Political Science, Newbury Park, Calif.: Sage Publications.

Barry, B. (2004), 'A Hundred Years of Studying Politics: What Have We Got to Show For It?' in J. Morrill (ed.), The Promotion of Knowledge: Lectures to Mark the Centenary of the British Academy, 1902-2002, Oxford: Oxford University Press.

Blunkett, D. (2000), 'Influence or Irrelevance: Can Social Science Improve Government?', Research Intelligence 71, pp. 12-21.

Cohn, J. (1999), 'When did Political Science Forget about Politics? Irrational Exuberance', New Republic $221(17)$, pp. 25-31.

Commission on the Social Sciences (2003), Great Expectations: The Social Sciences in Britain, Academy of Learned Societies for the Social Sciences.

Donovan, C. (2005), 'The Governance of Social Science and Everyday Epistemology', Public Administration 83(3), pp. 597-615.

Dryzek, J. (2003), 'A Pox on Perestroika, a Hex on Hegemony: Towards a Critical Political Science', Social and Political Theory Program Working Paper, The Australian National University. http://socpol.anu.edu.au/pdf-files/Dryzek\%20pox.pdf.

Edwards, M. (2004), Social Science Research o Public Policy: Narrowing the Divide, Policy Paper 2, Academy of the Social Sciences in Australia, Canberra.

Hammersley, M. (2001), ‘The Sky is Never Blue for Modernisers: The Threat Posed by David Blunkett's Offer of "Partnership" to Social Science', Research Intelligence 72, pp. 12-14.

Hardin, R. (2002), 'Whither Political Science', PS: Political Science e Politics 35(2), pp. 183-186.

Heyworth, G. (1965), Cmnd. 2660, Report of the Committee on Social Studies, London: HMSO.

Lewis, J. (2003), 'How Useful are the Social Sciences?', The Political Quarterly 74(2), pp. 193-201.

McGrath, C. (2001), Influencing the UK Policymaking Process, Swindon: Economic Social and Research Council.

Rothschild, V. (1982), Cmnd. 8554, An Enquiry into the Social Science Research Council, London: HMSO.

Sartori, G. (2004), 'Where is Political Science Going?', PS: Political Science e Politics 37(4), pp. 785-787.

Smith, R.M. (2002), 'Should we Make Political Science more of a Science or more about Politics?', PS: Political Science e Politics 35(2), pp. 199-201.

Stone, D., S. Maxwell and M. Keating (2001), 'Bridging Research and Policy', Paper given at an International Workshop funded by the UK Department for International Development, Warwick University, 16-17 July. www.gdnet.org/pdf/Bridging.pdf.

The Sussex Editorial Team (2000), 'Editorial', Politics 20(2), 51-53. 